DOI https://doi.org/10.36059/978-966-397-225-1-13

\title{
DANCING IN JAZZ: FROM ORIGIN TO THE PRESENT
}

\section{Tormakhova Veronika}

\section{INTRODUCTION}

In the primary forms of culture, there was an inseparable connection between dance and music, which, combined in syncretic action, had an important sacred significance. However, gradually the formation of dance and music forms became apparent, which demonstrated their already purely applied nature, taking on the meaning of entertainment, consolation, forms of leisure. Jazz is one of the musical trends which combines highly artistic and entertaining beginnings. The leading characteristics of this direction of musical art are freedom, improvisation, attention to the rhythmic beginning. This branch of music has a large audience. The synthetic nature of jazz contributed to the fact that it was capable of variability. Absorbing elements of some genres (gospel, blues), he was inclined to transform them into a fundamentally new phenomenon. The development of jazz art came a long way, characterized by the decline of some styles and the formation of others. Currently, there is virtually simultaneous operation of all jazz directions. However, not all of them were equally popular with the general public. The directions for which the dancing beginning was inherent had considerable distribution. In particular, such jazz styles are swing, funk. Although virtually all styles of jazz are closely related to a specific metrorhythmic organization (the "swinging" principle), which distinguishes them from academic artistic practice, the level of "dancing" in them was quite different. Sometimes jazz rhythms showed a wide range of rhythmic patterns: from the full a-dance of be-bop to extremely dance funk. An urgent task is to analyze the peculiarities of the interaction of jazz art and choreography of the 20th century, the correlation between the dance beginnings and other genre origins in jazz styles.

Issues related to the study of jazz art have already found coverage in Art History discourse. In particular, the origin of jazz was outlined by V. Konen. G. Baghdasaryan studied the problem of rhythmic organization and development of the rhythm section. Dance practices of the African population became the subject of investigations by S. Kovaleva and V. Karpenko. Some jazz styles were analyzed by M. Smorodska, V. Tormakhova, I. Yarkina, but dance in jazz has not yet become the subject of separate development. 
The purpose of the study is to identify the features of the jazz formation, the specifics of the genesis of dance, which is available in different jazz areas and trends in its development.

\section{Rhythm, Dance and Percussion Instruments as a Component of the Development of Ethnic Cultures}

The dance was given an important role in the basis of ancient ethnic cultures. His existence in the context of culture differed significantly from the Western European type. This was the art of not professionals, in the full sense of the word, but a specially trained part of the tribe. The lack of separation between the public and the dancers, which was characteristic of African tribes, meant that everyone was united in common dance practice. A number of researchers of the culture of the tribes of the African continent have pointed out that dance was extremely important. In particular, S. Kovaleva and V. Karpenko pointed out that the dance arose from a ritual action, which had almost an artistic-aesthetic, but an applied practical function. It is rooted in "certain conditions of its implementation and perception, with a specific life situation"1. Dance for African tribes, as in the case of Indian culture, was a component of worship. "Cult dances had a majestic, austere, solemn character; movement and music in them were often strictly regulated and conditioned by the peculiarities of the ceremony" ${ }^{\prime 2}$. This trait was similar to those of other cultures.

The basis of ethnic music of Africans was the sphere of rhythm. Percussion instruments have long been an integral part of it. As in most ancient nations, whose culture went through a stage of primitive order, the rhythmic beginning was syncretically connected with movement, dance, magical action. Playing percussion instruments was important while maintaining the signal and communication function. Karl Bucher noted the important role that rhythm played at the level of physiology. "Rhythm evokes a pleasant feeling; therefore, it serves not only to facilitate the work, but also one of the sources of aesthetic pleasure and the element of art, the feeling of which is inherent in all people from birth, no matter what level of education they are" ${ }^{3}$. Most likely, it was out of the need to hide the activity

${ }^{1}$ Kovaleva S. M., Karpenko V. N. (2016) Tanets kak svyashchennyy ritual narodov Afriki [Dance as a sacred ritual of the peoples of Africa]. Symbol of Science, no. 4, pt. 4, p. 133.

${ }^{2}$ Kovaleva S. M., Karpenko V. N. (2016) Tanets kak svyashchennyy ritual narodov Afriki [Dance as a sacred ritual of the peoples of Africa]. Symbol of Science, no. 4, pt. 4, p. 133.

${ }^{3}$ Bucher K. (1899) Rabota i ritm. Rabochie pesni, ikh proiskhozhdenie, esteticheskoe $i$ ekonomicheskoe znachenie [Work and rhythm. Working songs, their origin, aesthetic and economic significance]. St. Petersburg: Knizhnyy magazin i kontora izdaniy O. Popovoy, p. 88 . 
of human nature that the practice of avoiding percussion instruments arose. Percussion instruments, which accompanied dance for a long time were also a "persona non grata". Dancing was a kind of antithesis to singing, which was able to "educate" through verbal text.

Interestingly, the notions of the afterlife in some African nations were associated with notions of a better existence in which the soul could have fun, namely - to spend time hunting and dancing. That is, dance is endowed with the meaning of consolation, for which there may not be enough space in real life. E. Taylor notes this in his work: "In the region of Kimbunda, in southwestern Africa, souls live in "Kalung", a world where there is a day when there is a night on the Earth. There is plenty of food and drink, women serve souls, hunting and dancing are a consolation, and in general, the afterlife is an adorned likeness of the present"4. Such a statement makes it possible to see that dance is part of the daily life of African peoples. In most ancient cultures, the syncretism of dance, music, and rituals were essential. The function of dance in ancient cultures may have been one that influenced the treatment of the patient.

Thus, Taylor points out that in the Indian archipelago they were convinced that the spirits that caused disease had a semi-human nature, so in order to remove them from the patient, you had to use the means to satisfy them - food, dance, celebration. "They [pathogenic spirits - V.T.] are pleased with holidays, dances and food displayed in the woods, in order to encourage them to leave their victims or send to the sea small boats with gifts so that the spirits that settled inside of the sick man could sit down in a boat and sail away forever. "That is, the role of dance in connection with rhythm, music, playing musical instruments acquires the role of a means of healing, accompanies a person in the afterlife, that is, it is an integral part of everyday life. J. Mikhailov notes that "African music throughout its history is closely linked with "parallel series" - a word or dance, a cult act or a social process. This "connection" of music makes it an integral part of African everyday life, and almost every member of the African community is equally its owner. After all, the social and cultural significance of music in the life of an African is an obvious fact" 5 .

The Sioux Winnebago (ho-chank) Indian people, who lived in what is now Wisconsin (near Lake Michigan), had the practice of being ordained

4 Taylor E. B. (1989) Pervobytnaya kul'tura [Primitive culture] (trans. Koropchevskiy D.). Moscow: Izdatel'stvo politicheskoy literatury, p. 213.

${ }^{5}$ Mikhailov J. (ed.) (1973) Ocherki muzykal'noy kul'tury narodov tropicheskoy Afriki [Essays on the musical culture of the peoples of tropical Africa]. Moscow: Muzyka, pp. 14-15. 
members of a witchcraft fraternity. It included dance performances that showed dynamics from a slow dance to fast, alternating with convulsive movements. "Adepts line up in one line and, each holding their medical bags with both hands, begin a dance accompanied by soft throat sounds. The pace of the dance, which is slow at first, accelerates as you approach the candidates, and at the same time, the sounds intensify, which finally turn into a deafening "wow!" when those who dedicate stop in front of the "contenders"," As part of rituals, dance in connection with rhythm was firmly rooted in the practices of ancient societies. Once again, for African ethnic groups, dance practices acted as a link to the traditions of previous generations. "Spiritual traditions of honoring ancestors exist in almost all cultures of African tribes, expressing sacred rituals through dance. The ancestors of the tribe are revered as spirits who maintain the ethical standards of life of the tribe. They are also perceived as mediators between people and divine force" 7 .

Gradually, dance practices, as having a syncretic character, are destroyed by setting new worldviews and replacing more separate artistic practices.

With the establishment of the first states, a gradual formation of a tendency to separate types of art was planned, which led to the formation of separate art forms that performed a specific function - from purely aesthetic to applied. Some musical samples had been established, which were used in worship services, while others had a more secular application. This practice developed in ancient civilizations, and later took root in Western Europe. It is extremely important to note that for many centuries in Western European music could be observed extremely limited use of percussion instruments. The sphere of rhythm, including unevenly accentuated, was mostly the basis of folk music. Dance forms that prevailed in different ethnic cultures were based on rhythms, often dotted, such that it is difficult to record within the classical system. This tradition of avoiding dancing in "serious music" was due to a number of reasons.

First of all, let us recall that the very sphere of rhythm and purely instrumental music, for a long time by theorists, since antiquity and, especially, the Middle Ages, was perceived as affective, devoid of educational potential. Aristotle also emphasized that music should be used for purification, for intellectual entertainment, they are able to convey

${ }^{6}$ Mikhailov J. (ed.) (1973) Ocherki muzykal'noy kul'tury narodov tropicheskoy Afriki [Essays on the musical culture of the peoples of tropical Africa]. Moscow: Muzyka, p. 360.

${ }^{7}$ Kovaleva S. M., Karpenko V. N. (2016) Tanets kak svyashchennyy ritual narodov Afriki [Dance as a sacred ritual of the peoples of Africa]. Symbol of Science, no. 4, pt. 4, p. 136. 
human feelings and transmit the qualities of character. The thinker noted that "rhythm and melody contain the closest to reality reflections of anger and meekness, courage and moderation and all the opposite properties, as well as other moral qualities. This is clear from experience: when we perceive the rhythm and melody in our ears, our mood changes" ${ }^{\prime 8}$. Instrumental music with clear and dance rhythms could distract from the perception of a verbal text, which alone had an impact on human consciousness. The ideas of music theorists were conditioned by the prevailing principles that determined the development of artistic practice. The dominance of the Christian worldview significantly inhibited the development of music, carrying out a fairly strict qualification of what could be performed, on what instruments, by what rules it was appropriate to write musical works.

\section{Change of World Views in the Musical Space of the 19th Century}

In the 19th century, the basis was formed for expanding the boundaries that existed in artistic practice. The focus on the Eurocentrism model, which was closely linked to the major-minor system, was gradually beginning to recede. That was a time when the foundations of classicism were finally losing their position in the field of preserving the unchanging classical musical genres, giving priority to the homophonic-harmonic style with the primacy of melody and genres that acquired their exemplary forms already. In the art of the classicist era, dance found a certain positive interpretation in the academic music field, while inventing development in other nonacademic areas. Classical composers introduced popular domestic dance genres into their own works and the image of the human was not something flawed" . The musical art of the Romantic era, with its interest in the realm of the senses, emphasized on the individual, the gradual introduction of elements that were inherent in other cultures - ethnic, unique in its originality, prepared the ground for expanded optics of different musical principles. The achievements of different cultures - at the level of melody, harmony, order, rhythm, instruments - were beginning to penetrate into the universal and balanced system of Western European art. The objective gives way to the subjective, the general was replaced by the singular, the absolute by the relative. The romantic worldview, which aroused interest in national

${ }^{8}$ Aristotle (1911) Politika [Politics] (trans. Zhebelev S. A.). Moscow: Izdanie M. i S. Sabashnikovykh, pp. 365-366.

9 Tormakhova A. M. (2009) Filosofiia muzyky v konteksti yevropeiskoi muzychnoi kultury XIX-XX st. [Philosophy of music in the context of European musical culture of the XIX-XX centuries], Kyiv: Taras Shevchenko National University of Kyiv, p. 171. 
schools, the uniqueness of ethnic origins, created the conditions for the perception of cultures and non-European origin.

Since the era of Romanticism there was a specific rehabilitation of the rhythmic beginning. Whimsical rhythmics began to be widely used by romantics, being borrowed from folklore sources. Such a dotted rhythm was characteristic of Hungarian, Polish, and Czech dance music, and it was through the formation of national schools of composition that they became known in other countries of Western and Eastern Europe. Gradually, a kind of pluralism of musical thinking was formed, which was based on the idea of updating genres, musical language and style.

This tendency was embodied in theoretical discourse, where more and more thinkers were beginning to "justify" certain areas of musical art, which were under a kind of "taboo" so far. For example, the representative of German classical philosophy F. Schelling would emphasize the leading role of rhythm, among other means of musical expression. "Schelling noted that for ancient thinkers, rhythm had the greatest aesthetic force; and hardly anyone would deny that everything really beautiful that was in the realms of

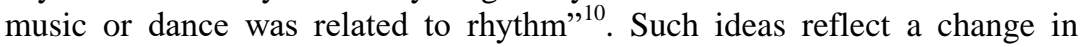
aesthetic guidelines, a change in the vector of development of scientific discourse and current trends that have manifested themselves in musical practice. However, the twentieth century will refuse to include dance in serious opuses. "Instead, composers of the 20th century. refuse to use simple household genres. Kholopov emphasizes that composers seek to avoid intersections with "too human" as a symbol of the low and the banal. In the 18 th -19 th centuries light folkdance music was a worthy object of high compositional creativity and in the twentieth century it ceased to be so» ${ }^{11}$.

\section{Formation of Jazz Art and its Synthetic Nature}

Jazz was becoming a new stage in the development of the music system. It absorbed completely different layers of music, transforming them into a new musical reality. "Jazz is basically a synthetic formation. It closely intertwines the ethnic origins of African culture - rhythms, order and genres formed in the process of clash with Christian religious beliefs (spiritual,

${ }^{10}$ Tormakhova A. M. (2009) Filosofiia muzyky v konteksti yevropeiskoi muzychnoi kultury XIX-XX st. [Philosophy of music in the context of European musical culture of the XIX-XX centuries], Kyiv: Taras Shevchenko National University of Kyiv, p. 76.

11 Tormakhova A. M. (2009) Filosofiia muzyky v konteksti yevropeiskoi muzychnoi kultury XIX-XX st. [Philosophy of music in the context of European musical culture of the XIX-XX centuries], Kyiv: Taras Shevchenko National University of Kyiv, p. 171. 
gospel and blues) and European academic music practice" ${ }^{12}$. The synthetic nature of jazz is noted by all researchers, emphasizing the leading role of all components that influenced its formation. "Jazz is music created mostly by black people in the United States in the early twentieth century. It arose due to the fusion of elements of Euro-American and African music. Jazz is a unique type of music that does not belong to the category of folklore, classical or pop music, but has some common features with these three types" $"$. Indeed, the art of jazz is a kind of meta-art that lies between academic music and folklore. It absorbs elements of both directions, but contrasts sharply with them. V. Konen characterizes jazz, as well as rock music by the art of the "third layer", indicating its belonging to a different type of musical creativity than the academic layer and folk" ${ }^{\prime 14}$. There are many definitions of jazz, but its constant features are improvisation, freedom in rhythmic and melodic dimensions. "First of all, this music is characterized by a complex rhythmic pattern, ensemble playing, polyphony, virtuosity, solo performance, a tendency to improvise, freedom of melody and harmonic idioms, which developed from simple diatonic through chromatic to atonality" "The second definition given in the dictionary is the following: "A characteristic style of dance music, characterized by certain features inherent in jazz"16. It is extremely important that this definition emphasizes the danceability of jazz as its immanent feature.

In the formation of jazz, its essential basis, undoubtedly played an important role in the music of people from Africa. This part of the population was extremely large in the United States. Representatives of various African tribes, which were brought to the territory of America, brought to its ethnically diverse picture and their own musical colors. Drums were an integral part of the culture of those from Africa who found themselves in the United States. Dan Emmett's "Orchestra" was based on the African-American folk tradition. All the instruments in the ensemble were used by musicians on plantations and designed by the Negroes themselves. Even in small slave ensembles there were necessarily percussion

12 Tormakhova V. (2020) Styleutvorennia v neakademichnii muzytsi [Creation of styles in non-academic music]. Humanities Science Current Issues, vol. 5, no. 29, pp. 210.

${ }^{13}$ Fisun M. (2017) The specifics of pop and jazz performance in soul style. National Academy of Managerial Staff of Culture and Arts Herald, no. 4, p. 276.

${ }^{14}$ Konen V. (1994) Tretiy plast: Novye massovye zhanry v muzyke XX veka [The third layer: New mass genres in the music of the twentieth century]. Moscow: Muzyka.

${ }^{15}$ Random House (1992) Jazz. Random House Webster's College Dictionary. New York: Random House Reference, p. 724.

${ }^{16}$ Random House (1992) Jazz. Random House Webster's College Dictionary. New York: Random House Reference, p. 724. 
instruments, such combinations as: "banjo and drum; banjo and tambourine; violin, triangle and "patting" (tapping rhythms with hands and feet); violin, bones and sticks, which were beaten on the floor; banjo, large bones (sawbones) and ordinary bones, etc." ${ }^{, 17}$.

Percussion instruments embodied that part of musical culture that was completely uncharacteristic of the professional school of composition, which developed until the 19th century. It is important to note that the tools themselves were banned. Noticing that black slaves were transmitting information from one plantation to another through drums, these instruments were confiscated. Representatives from almost two thousand tribes came to the territory of the USA, but their music had a lot in common in terms of rhythm. "Two or more rhythmic patterns are superimposed on each other. The simplest example is the simultaneous playing of two reels, when one of them performs three parts, and the other at the same time - two. However, such a simple combination of rhythms is rare. Much more often, each of the three or six instruments performs simultaneously with the others its rhythmic figure, and each of them has its own size (meter), or, as jazzmen say, its own "bit"18. The rhythmic structure inherent in jazz at the time of its formation is closely linked to African musical traditions. It is a complex rhythmic organization that was extremely different from the European one. M. Smorodska notes the typical rhythmic structures characteristic of African music: "African music is usually inextricably linked with rhythmic polyphony. The ground beat (basic rhythmic pulse), which can be set by the drum, the dancer's movements or applause, remains unchanged. One or more rhythmic voices assigned to drums or other instruments, dancers or singers are superimposed on the foot-beating ground beat."19.

The sphere of rhythm, represented in the first forms of jazz, the use of various percussion instruments, were radically different from the musical product that prevailed in the 19th century. It absorbed the African rhythm, combining it with elements of European practice. Ragtime became the forerunner of jazz. This direction became a kind of bridge between professional academic creativity and jazz itself. It already has the principle

17 Konen V. (1984) Rozhdenie dzhaza [The birth of jazz]. Moscow: Sovetskiy kompozitor, p. 125.

${ }_{18}$ Baghdasaryan G. E. (2015). Razvitie metroritmicheskikh sposobnostey v protsesse obucheniya na udarnykh instrumentakh [Development of metrorhythmic abilities in the process of learning on percussion instruments] ( $\mathrm{PhD}$ Thesis), St. Petersburg: St. Petersburg State Institute of Culture, p. 15.

${ }^{19}$ Smorodska M. M. (2020) Styl soul v estradno-dzhazovomu vokalnomu mystetstvi druhoi polovyny XX stolittia [Soul style in pop and jazz vocal art of the second half of the XX century] (PhD Thesis), Kharkiv: Kharkiv State Academy of Culture, p. 61. 
of polyrhythm, syncope. Undoubtedly, the nature of ragtime is also danceable. However, it does not yet have all the freedom that was already inherent in jazz forms. V. Konen notes that it refracts "in a simplified form the main principle of the drum ensembles of the Black Continent" ${ }^{20}$. It is extremely important that the rhythmic structure of ragtime influenced the development of the choreography of the century. "With the exception of the waltz (probably immortal!), Its typical examples of the last century - polka, quadrille, gallop, cancan - have been replaced by cakewalk, foxtrot, tango and gone forever. Foxtrot, which arose from cakewalk, began to dominate unconditionally" ${ }^{21}$. Neither the intonation organization nor the principles of formation, which were in ragtime, did not contradict the system of European music. However, the following forms that emerged after ragtime could be clearly differentiated from academic music practice. If we turn to the analysis of those components that spread in jazz from the European music system, they are mostly associated with the spread of ensemble and orchestral music, with the penetration of elements of major-minor system, the creation of certain stable elements of the overall musical whole. The first of the purely jazz trends was Dixieland - New Orleans style.

It originated in the 1920s in New Orleans, and its specificity was associated with collective music. Of course, immersing yourself in the history of jazz art, we can conclude that not all styles of jazz had the same dance nature. However, it was Dixieland, widespread in New Orleans, that became the first jazz direction to be fully danceable in nature. New Orleans jazz was characterized by the use of a fairly large composition. It used instruments common in academic practice - cornet, trumpet, double bass. Also, one of the common instruments was the banjo, which would later be in fact removed from jazz. To a large extent, the variability of the performance was due to the presence of instruments and performers who played them. The essence of jazz art in terms of rhythmic organization is to change orientations, from melody to rhythmic dance, which resembles syncretized forms. "Jazz returns rhythm in music to its primary function of organizing movement, gesture, body art, dance as an artificated variant of the embodiment of motor functions in their synthetic musical-dance embodiment. The rhythm in jazz is specified due to the constant

${ }^{20}$ Konen V. (1994) Tretiy plast: Novye massovye zhanry $v$ muzyke XX veka [The third layer: New mass genres in the music of the twentieth century]. Moscow: Muzyka, p. 76.

${ }^{21}$ Konen V. (1994) Tretiy plast: Novye massovye zhanry v muzyke XX veka [The third layer: New mass genres in the music of the twentieth century]. Moscow: Muzyka, p. 76. 
syncopation, shifts of the supporting lobes of metrized bars, which is directly related to the non-European (African) origins of jazz style"22.

The next direction of jazz, which had a pronounced dance nature, was swing. This style became a kind of reconciliation with jazz. Its significant commercialization contributed to the fact that it spread among the white population, acquiring many features of academic practice. First of all, there was a change in the location where the music was presented. Those were no longer small groups of musicians moving through the streets of New Orleans, but large orchestras playing indoors, halls, dance floors, restaurants. There was an increase in the number of members of the orchestra, a big band was formed, which already presents whole groups of similar instruments, there were parts performed by several members. "Swing was based on the variety, commercial variety of jazz, but "polished" its sharp sounds, streamlined the techniques of formation and turned the quantitatively modest composition of the jazz band into a very large orchestra - the so-called "big band" 23 . Therefore, the practice of arranging, which was used by the leaders of orchestras, writing scores, attracting musicians who had a musical education was necessary. Despite the formation of a more professional approach, this direction has a dancing nature. Swing as a dance became common, fostering interest in jazz. Swing became a new starting point in the spread of dance forms of the 20th century. He led to the formation of new dances, while becoming the most choreographed style of jazz. Although this principle helped to reduce other characteristics that were already present in New Orleans jazz - it was improvisation and greater freedom.

It should be noted that certain areas of jazz, as already mentioned, may have a lower level of dancing. This applies in particular to beep, free jazz and a number of others. The formation of the beep-bop style was just a reaction to the change in the direction of jazz development, which was demonstrated by swing. Bee-bop took a fundamentally non-dance position, which was aimed at reducing the commercialization of jazz. The formation of music at a very fast pace, complex improvisations, the use of small performances, where virtually every musician was a soloist - was the complete opposite of swing. Similarly, the transfer of jazz compositions to small clubs contributed to the fact that it would be impossible to dance to this music, even in theory. Such an a-dance nature contributed to

${ }^{22}$ Yarkina I. Yu. (2016) Vokalno-instrumentalnyi ansambl u styli funk [Vocal and instrumental ensemble in funk style] ( $\mathrm{PhD}$ Thesis), Kharkiv: Kharkiv National I. P. Kotlyarevsky University of Arts, p. 23.

${ }^{23}$ Konen V. (1994) Tretiy plast: Novye massovye zhanry $v$ muzyke XX veka [The third layer: New mass genres in the music of the twentieth century]. Moscow: Muzyka, p. 112. 
the formation of a not very large audience and the elitization of this area. For the most part, other jazz styles that emerged after the bebop era developed in two directions - more elitist, more experimental, and more danceable, which continued the direction of commercial swing. According to V. Konen, such dualism was already in the swing era, and even earlier than it, when there was a "combed" ("sweet" or "straight" type of jazz) and "hot" jazz. The first variety was characterized by very moderate improvisation, when the only area of freedom was "breaks", while hot jazz became a real center for free improvisation and a-dance. "It was during the years of swing domination in jazz culture that there were two clear, opposite directions - commercial swing and improvisational Negro jazz" ${ }^{24}$. A number of authors note that the development of dance, which was contained in the swing, after the era of bebop, began to move not only in jazz, but also to a greater extent in pop music, which took over the dance beginnings. "The main trends here were: 1) preservation of vocal origin (song-dance) in such styles as Rhythm \& Blues, jazz-rock, soul; 2) "heading" into the realm of "pure" rhythmic and dance elements in the styles of disco and hip-hop, which have already budged from jazz and are stylistically part of pop music" 25 .

Of course, one of the most dancing areas of jazz in the late period were the branches, which can be attributed to Latin jazz (Bossa nova, etc.) and funk. The promotion of Latin American music in the United States dates back to the 60 s of 20 th century. The formation of a specific metrorhythmic principle, which was characteristic of Latin American folklore, very easily penetrated into the already established jazz structures. Latin American songs were inextricably linked to dance and were emphasized by bright rhythms, which were emphasized by numerous percussion instruments. A variety of percussion instruments were quite common, from drums to ordinary sticks, which were struck on the ground to replace the castanets or heels of the dancer. Cuban instruments, such as claves and the more international Congo bamboula also were also common.

We must distinguish between purely Latin American dance music and jazz trends. So Bossa nova is a jazz style, although it is often confused with rumba, mamba and cha-cha-cha. "However, in reality, Bossa nova is a jazz style created by Antonio Carlos Jobim, Joao Gilberto, Vinicius de Moraes, Luiz Bonfa and Newton Mendonca. Naturally, we must mention the famous

${ }^{24}$ Konen V. (1994) Tretiy plast: Novye massovye zhanry $v$ muzyke XX veka [The third layer: New mass genres in the music of the twentieth century]. Moscow: Muzyka, p. 113.

${ }^{25}$ Yarkina I. Yu. (2016) Vokalno-instrumentalnyi ansambl u styli funk [Vocal and instrumental ensemble in funk style] (PhD Thesis), Kharkiv: Kharkiv National I. P. Kotlyarevsky University of Arts, p. 62. 
saxophonist Stan Getz, who had a huge impact on the formation of the style of Bossa nova" ${ }^{26}$. The rhythmic basis of this direction was to emphasize the 3 rd part of the bar, while the swing focused on the 2nd and 4th part. Bossa nova itself originated in Brazil as a form of American jazz, but later spread to other countries. G. Baghdasaryan notes that the success of the Bossa nova depended not only on the solo on the saxophone, but also on the rhythm section. Guitarist Charlie Byrd's play was admirable. In fact, Latin American music played a significant role in everyday life, combining different ethnic components: Spanish (or Portuguese), African and Indian musical cultures, Central American music, Caribbean, Argentine and Mexican music, although sometimes there was more relatedness between them. It was difficult to separate them. Accordingly, this jazz direction is closely related to dance practices that demonstrate a focus on Latin American rhythms and instruments. Here it is worth mentioning the typical timbre color of the vocalists' voices, manner of playing and techniques of sound production on instruments.

If we talk about another branch of jazz, which has a pronounced dance nature, i.e. funk, its structure is closely related not only to the rhythmic characteristics, but a whole complex, which consists of certain timbre and texture patterns that enhance the dance principle. This characteristic of funk is outlined by I. Yarkina. "Spatialization" ("spatializing") of time in plastic dance genres NRM ("new rhythmic music") is directly related to texture, more broadly - with the timbre-texture complex, represented in the phonics of ensembles and soloists who turn to this kind of music. Along with the preservation of the traditional for the genres of the "third" layer of the song and dance basis with its characteristic "division of time at the level of fate" (T. Adorno), in rhythmic entertainment and dance music a timbre modification takes place" ${ }^{, 2}$. Those jazz styles that emerge after bebop are already difficult to classify by performance or belonging to a commercial or non-commercial type of music. Purely musical principles of organization of musical fabric, which distinguish one style from another, come to the fore. Funk is characterized by the preservation of the basic postulates of traditional jazz, which give this direction a dance nature - it is "reliance on swing as the main rhythmic source of jazz improvisation with a shift of

${ }^{26}$ Baghdasaryan G. E. (2015). Razvitie metroritmicheskikh sposobnostey v protsesse obucheniya na udarnykh instrumentakh [Development of metrorhythmic abilities in the process of learning on percussion instruments] ( $\mathrm{PhD}$ Thesis), St. Petersburg: St. Petersburg State Institute of Culture, p. 25.

27 Yarkina I. Yu. (2016) Vokalno-instrumentalnyi ansambl u styli funk [Vocal and instrumental ensemble in funk style] (PhD Thesis), Kharkiv: Kharkiv National I. P. Kotlyarevsky University of Arts, p. 43. 
emphasis on the strong parts associated with dance" 28 , in addition, blues-like shapes and a structure that includes the use of one or more reefs that become part of improvisational passages are preserved.

It should be noted that the forms of jazz presented in the modern music space continue the practice of balancing between dance and non-dance beginnings. In particular, a number of directions that have formed relatively recently - cool jazz, smooth jazz, etc. - focused on the format of listening. They are endowed with a number of characteristics that require careful listening attention, because they are the product of a highly intelligent creative process. "Modern jazz, formed today, includes a number of branches that had different names (cool jazz, intellectual jazz and others), is the most interesting art, often contemplative, based on extremely complex group improvisation, a subtle timbre color, virtuoso performance and original harmonious style" ${ }^{29}$. At the same time, there are still groups that focus on the performance of Latin jazz, which is impossible in the format of pure listening, but rather interconnected with the dynamics of the dance movement.

\section{CONCLUSIONS}

Jazz is a direction of musical art, which was formed under the influence of various factors. These are the cross-cultural connections that influenced the formation of the new musical layer. Jazz was a form of artistic practice that combined the achievements of ethnic cultures and academic music. Jazz art has become a product of the new on the basis of already constant elements. However, it has not changed its nature and is characterized by significant variability, easily combined with musical directions and creating something new on this basis. The rhythmic side inherent in African musical ethnic cultures played an important role in the formation of jazz.

For ancient cultures, the sphere of rhythm and dance were the basis of life practices. They had different purposes and specifics, but were immanently present in everyday life. Freedom of rhythm, the principle of swinging, attention to dotted rhythms and emphasizing the weak parts of the beat gave jazz dance, which is available in a number of jazz styles. We can note the line of development of dance practices from syncretic practices to synthesis, which emerged in the 20th century.

${ }^{28}$ Yarkina I. Yu. (2016) Vokalno-instrumentalnyi ansambl u styli funk [Vocal and instrumental ensemble in funk style] ( $\mathrm{PhD}$ Thesis), Kharkiv: Kharkiv National I. P. Kotlyarevsky University of Arts, p. 65.

${ }^{29}$ Konen V. (1994) Tretiy plast: Novye massovye zhanry v muzyke XX veka [The third layer: New mass genres in the music of the twentieth century]. Moscow: Muzyka, p. 114. 
The general pattern of development of jazz demonstrates the existence of two lines of development. One of which is a more commercial, dance line, which includes swing, barefoot, funk. The other is related to the prevalence of experiment, improvisation, technical complexity, which give the areas a more elitist character. These are bee-bop, cool jazz, free jazz, fusion, which focus on listening to songs rather than performing dance movements during music. Despite the fact that jazz styles have been formed over a long period of time, all of them do not cease to exist, but continue to function simultaneously.

\section{SUMMARY}

Jazz art is an important part of modern culture. The emergence of jazz marked a turn to new layers of musical culture - to come to the forefront of rhythm and improvisational freedom. These features of jazz art are closely linked to the origins of jazz, which lie in African folklore and academic music practice. Relying on such genres as gospel, blues and spiritual was the first step in the formation of modern jazz. This direction of musical art has demonstrated the ability to easily transform. The leading features of a number of jazz trends are bright dancing nature. The interaction between musicians and the public is reminiscent of the forms of syncretic action that were the basis of most cultures.

In the primary forms of culture there was an inseparable connection of dance and music principles, which, combined in syncretic action had an important sacred significance. The connection between rhythm and dance, which was characteristic of early cultures, were unknown to academic music culture for a long time. However, with the birth of jazz, dance was restored, which contributes to the formation of a new type of choreography in the 20th century. Freedom of rhythm, the principle of swinging, attention to syncopated rhythms and emphasizing the weak parts of the beat are the basis of jazz dancing. The general pattern of development of jazz demonstrates the existence of two lines of development.

One of which is a more commercial, dance line, which includes swing, barefoot, funk. The other is related to the prevalence of experiment, improvisation, technical complexity, which give the areas a more elitist character. These are bee-bop, cool jazz, free jazz, fusion, which focus on listening to songs rather than performing dance movements during music. Despite the fact that jazz styles have been formed over a long period of time, all of them do not cease to exist, but continue to function simultaneously. 


\section{REFERENCES}

1. Aristotle (1911) Politika [Politics] (trans. Zhebelev S. A.). Moscow: Izdanie M. i S. Sabashnikovykh. (in Russian)

2. Baghdasaryan G. E. (2015). Razvitie metroritmicheskikh sposobnostey $v$ protsesse obucheniya na udarnykh instrumentakh [Development of metrorhythmic abilities in the process of learning on percussion instruments] (PhD Thesis), St. Petersburg: St. Petersburg State Institute of Culture.

3. Bucher K. (1899) Rabota i ritm. Rabochie pesni, ikh proiskhozhdenie, esteticheskoe $i$ ekonomicheskoe znachenie [Work and rhythm. Working songs, their origin, aesthetic and economic significance]. St. Petersburg: Knizhnyy magazin i kontora izdaniy O. N. Popovoy. (in Russian)

4. Fisun M. (2017) The specifics of pop and jazz performance in soul style. National Academy of Managerial Staff of Culture and Arts Herald, no. 4, pp. 276-280.

5. Konen V. (1984) Rozhdenie dzhaza [The birth of jazz]. Moscow: Sovetskiy kompozitor. (in Russian)

6. Konen V. (1994) Tretiy plast: Novye massovye zhanry v muzyke $X X$ veka [The third layer: New mass genres in the music of the twentieth century]. Moscow: Muzyka. (in Russian)

7. Kovaleva S. M., Karpenko V. N. (2016) Tanets kak svyashchennyy ritual narodov Afriki [Dance as a sacred ritual of the peoples of Africa]. Symbol of Science, no. 4, pt. 4, pp. 133-136.

8. Mikhailov J. (ed.) (1973) Ocherki muzykal'noy kul'tury narodov tropicheskoy Afriki [Essays on the musical culture of the peoples of tropical Africa]. Moscow: Muzyka. (in Russian)

9. Random House (1992) Jazz. Random House Webster's College Dictionary. New York: Random House Reference, p. 724.

10. Smorodska M. M. (2020) Styl soul v estradno-dzhazovomu vokalnomu mystetstvi druhoi polovyny XX stolittia [Soul style in pop and jazz vocal art of the second half of the XX century] (PhD Thesis), Kharkiv: Kharkiv State Academy of Culture.

11. Taylor E. B. (1989) Pervobytnaya kul'tura [Primitive culture] (trans. Koropchevskiy D.). Moscow: Izdatel'stvo politicheskoy literatury. (in Russian)

12. Tormakhova A. M. (2009) Filosofiia muzyky v konteksti yevropeiskoi muzychnoi kultury XIX-XX st. [Philosophy of music in the context of European musical culture of the XIX-XX centuries], Kyiv: Taras Shevchenko National University of Kyiv. 
13. Tormakhova V. (2020) Styleutvorennia v neakademichnii muzytsi [Creation of styles in non-academic music]. Humanities Science Current Issues, vol. 5, no. 29, pp. 209-212.

14. Yarkina I. Yu. (2016) Vokalno-instrumentalnyi ansambl u styli funk [Vocal and instrumental ensemble in funk style] (PhD Thesis), Kharkiv: Kharkiv National I. P. Kotlyarevsky University of Arts.

Information about the author:

Tormakhova Veronika orcid.org/0000-0003-3821-0655

$\mathrm{PhD}$ in Music

Kyiv National University of Culture and Arts 36, Ye. Konovaltsia Str., Kyiv, 01133, Ukraine 